Al-Manhaj: Jurnal Hukum dan Pranata Sosial Islam

Vol. : : 2 (2), 2020, 167-194

P-ISSN : 2686-1607

E-ISSN : 2686-4819

\title{
PERSPEKTIF HUKUM ISLAM TENTANG PERNIKAHAN DI LUAR KANTOR URUSAN AGAMA DI BANDAR LAMPUNG
}

\author{
M. Ma'shum Ridho, Abd. Qohar \\ Universitas Islam Negeri Raden Intan Lampung \\ email: ridho.amanah16@gmail.com,abdul.qohar@radenintan.ac.id
}

Abstract: The tendency of the Bandar Lampung community to choose to carry out marriages outside the Office of Religious Affairs, this is a unique problem and needs to be conducted in a study of the Mandalam. In this paper aims to discuss the factors that cause marriages outside the Office of Religious Affairs in Bandar Lampung City. In this research the method used is a qualitative method, the type of field research, with a sociological juridical approach. Based on the results of the study it was found, that the factors that caused the community to prefer a marriage contract outside the KUA, among others; Customary / traditional factors, more solemn, sacred, comfortable and memorable, can be seen by many people, avoiding gossip and negative images, as well as more easy, simple and practical. The reason is if classified based on traditional factors, there are also factors found ease and comfort. The reason was generated from the statements of various sources with different social backgrounds. Each has its own reasons. But there are still many assumptions of the community who consider the implementation of marriage in the KUA office to spend a lot of money. Increasing the implementation of marriages outside KUA due to lack of socialization carried out by the KUA of Tanjung Karang, Kedaton and Panjang districts, the effectiveness of marriages at the KUA office

Keywords: Islamic law, Marriage, Office of religious affairs 
Abstrak: Adanya kecenderungan masyarakat Bandar Lampung untuk memilih melaksanakan perkawinan diluar Kantor Urusan Agama, hal tersebut menjadi persoalan yang unik dan perlu dilakukan pengkajian mandalam. Dalam tulisan ini bertujuan untuk membahas faktor-faktor yang menyebabkan terjadinya pernikahan di luar Kantor Urusan Agama di Kota Bandar Lampung. Pada penelitan ini metode yang digunakan adalah metode kualitatif, jenis penelitian field research, dengan pendekatan yuridis sosiologis. Berdasarkan hasil penelitian ditemukan, bahwa faktor yang menyebabkan masyarakat lebih memilih akad nikah di luar KUA, antara lain; Faktor adat / tradisi, Lebih khidmat, sakral, nyaman dan berkesan, Dapat disaksikan orangbanyak, Menghindari gosip dan image negative, serta lebih mudah, simple dan praktis. Alasan tersebut jika diklasifikasikan ada yang berdasarkan faktor tradisi ada juga didilandasi faktor kemudahan dan kenyamanan. Alasan tersebut dihasilkandari pernyataan berbagai narasumber dengan latar belakang sosial yang berbeda. Masing-masing memiliki alasan tersendiri. Namun masih banyaknya asumsi masyarakat yang menilai pelaksanaan menikah dikantor KUA mengeluarkan biaya yang tidak sedikit. Peningkatan pelaksanaan pernikahan diluar KUA karena kurangnya sosialisasi yang dilakukan oleh pihak KUA kecamatan Tanjung Karang, Kedaton dan Panjang efektifnya pelaksanaan pernikahan dikantor KUA.

Kata Kunci: Hukum Islam, Pernikahan, Kantor Urusan Agama.

\section{PENDAHULUAN}

Pernikahan atau perkawinan ialah ikatan lahir batin antara seorang pria dengan seorang wanita sebagai suami istri dengan tujuan membentuk keluarga (rumah tangga) yang bahagia dan kekal berdasarkan KeTuhanan Yang Maha Esa1 ${ }^{1}$ Membentuk sebuah rumah tangga yang bahagia dan kekal adalah impian dan

1 Pasal 1 Undang-undang Nomor 1 Tahun 1974 tentang Perkawinan. 
M. Ma'shum Ridho \& Abd. Qohar, Perspektif Hukum Islam Tentang Pernikahan .... 169 dambaan bagi setiap orang. Untuk membentuk keluarga yang sejahtera dan bahagia tersebut, maka diperlukan adanya perkawinan antara seorang laki-laki dan perempuan. Tidak ada sebuah keluarga tanpa adanya perkawinan yang sah sesuai dengan norma agama dan tata aturan yang berlaku. Perkawinan tersebut akan menghalkan hubungan antara seorang laki-laki dan perempuan.

Pelaksanaan pernikahan yang terjadi di masyarakat kadang-kadang ditemui pasangan pengantin yang masih relatif muda dan bahkan dilaksanakan diluar KUA. Masalah usia nikah ini merupakan salah satu faktor yang penting dalam persiapan pernikahan. Karena usia seseorang akan menjadi ukuran apakah ia sudah cukup dewasa dalam bersikap dan berbuat atau belum. Kematangan atau kedewasaan usia kawin, baik persiapan fisik dan mental seperti yang disebutkan dalam Undang-Undang Pernikahan No.1 Tahun 1974. Fenomena sosial menunjukkan bahwa kondisi masyarakat modern dewasa ini jauh dari ketentraman, tak terkecuali keluarga yang merupakan unit terkecil dari masyarakat juga terjangkit berbagai penyakit seperti penyelewengan seksual, keluarga awet rajet (dalam rumah tangga tak pernah rukun), penggunaan obat-obat terlarang, keluarga serakah yang mengakibatkan korupsi, keluarga berantakan dan lain-lain.

Secara teoritis kepatuhan masyarakat terhadap hukum sangat terkait dengan kesadaran hukum masyarakat itu sendiri. Kepatuhan masyarakat terhadap hukum sangat tergantung kepada pengetahuan mereka terhadap ketentuan-ketentuan kaedah 
hukum, kemudian timbul kesadaran hukum, sehingga hukum dapat dilaksanakan sesuai dengan dengan yang dicitakan. ${ }^{2}$

Namun budaya perkawinan dan aturannya yang berlaku pada suatu masyarakat atau pada suatu bangsa, tidak terlepas dari pengaruh budaya dan lingkungan dimana masyarakat itu berada serta pengetahuan, pengalaman, kepercayaan dan keagamaan yang dianut masyarakat bersangkutan. Seperti hnya aturan perkawinan bangsa Indonesia, bukan saja dipengaruhi adat budaya masyarakat setempat tetapi juga dipengaruhi ajaran agama, bahkan juga dipengaruhi budaya barat. Jadi, walaupun Bangsa Indonesia kini telah memiliki hukum positif sebagai landasan dasar pemanfaatan dan penggunaan balai pernikahan di KUA, tapi masyarakat Indonesia masih tetap enggan dan kurang berminat untuk memanfaatkannya.

Berdasarkan Keputusan Menteri Agama No.517 Tahun 2001 tentang penataan organisasi KUA Kecamatan, tugas KUA adalah melaksanakan sebagian tugas dari Kantor Departemen Agama Kabupaten dan Kota dibidang Urusan Agama Islam dalam wilayah kecamatan. Keberadaan KUA merupakan bagian dari institusi pemerintah daerah yang bertugas memberikan pelayanan kepada masyarakat. Sebagai ujung tombak pelaksanaan tugas umum pemerintah, khususnya di bidang urusan agama islam, KUA telah berusaha seoptimal mungkin dengan kemampuan dan fasilitas yang ada untuk memberikan pelayanan yang terbaik, dan

2 Nur A Fadhil Lubis, Hukum Islam dalam Kerangka Teori Fikih dan Tata Hukum Indonesia (Medan: Widiyasarana, 1995), 126. 
M. Ma'shum Ridho \& Abd. Qohar, Perspektif Hukum Islam Tentang Pernikahan .... 171 juga KUA sebagai institusi pemerintah juga berkewajiban untuk membina kerukunan antar umat beragama. Dalam upaya peningkatan kualitas pelayanan, pemerintah memberikan fasilitas tambahan kepada masyarakat. Yaitu dengan memberikan balai nikah di seluruh KUA di Indonesia, termasuk di KUA. sehingga masyarakat dapat melaksanakan pernikahan di KUA. Pada balai nikah yang ada di KUA Bandar Lampung juga menyediakan pelayanan tambahan gratis bagi masyarakat. Akan tetapi pada kenyataannya, balai nikah tetap kurang diminati oleh masyarakat. Masyarakat lebih memilih melaksanakan pernikahannya di luar balai nikah. Padahal jika ingin melaksanakan pernikahan di luar balai nikah, maka calon pengantin akan mengalami kerepotan dengan menyiapkan segala sesuatu untuk pelaksanaan akad nikah tersebut.

Berdasarkan uraian di atas maka paper ini akan membahas factor-faktor yang menyebabkan terjadinya pernikahan di luar Kantor Urusan Agama Kota Bandar Lampung. Pada penelitan ini metode yang digunakan adalah metode penelitian kualitatif, jenis penelitian field research, dengan pendekatan yuridis sosiologis.

\section{PENGERTIAN PERKAWINAN}

Perkawinan dalam bahasa arab dikenal dengan istilah annikah. ${ }^{3}$ an-Nikah yang bermakna al-wat'u dan ad-dammu wa attadakhul, kadangkala juga disebut dengan ad-dammu wa al-jam'u

3 Mahmud Yunus, Kamus Arab Indonesia (Jakarta: Yayasan Penyelenggara Penterjemah/ Pentafsiran Al-Qur'an, 1973), 468. 
yang bermakna bersetubuh, berkumpul dan akad. ${ }^{4}$ Bahkan perkawinan dalam literatur fiqh di sebut dengan dua kata nikah dan $z_{a w a j}$. Kedua kata ini yang biasa di pakai dalam kehidupan sehari-hari dan banyak terdapat dalam Al-qur'an maupun hadist Rasulullah Muhammad SAW.

Sementara makna nikah (kawin) dalam perspektif sosiologis bahwa perkawinan merupakan suatu proses pertukaran antara hak dan kewajiban serta penghargaan dan kehilangan yang terjadi antara sepasang suami istri. Oleh karena perkawinan merupakan proses integrasi dua individu yang memiliki latar belakang sosial budaya, serta keinginan dan kebutuhan yang berbeda, maka proses pertukaran dalam perkawinan ini harus senantiasa di rundingkan dan di sepakati bersama. ${ }^{6}$ Sehingga dalam konteks sosiologis, bahwa perkawinan tidak akan terjadi apabila tidak ada kesepakatn bersama, yakni untuk bersama-sama mengarungi bahtera rumah tangga.

Dengan demikian, perkawinan adalah akad/perjanjian yang menghalalkan pergaulan, membatasi hak dan kewajiban, serta sikap tolong menolong antara seorang pria dan seorang wanita yang keduanya bukan muhrim. ${ }^{7}$ Sehingga terbentuklah fungsi masing-masing pihak sebagai akibat dari adanya ikatan lahir batin,

4 Amir Nuruddin dan Azhar Akmal Tarigan, Hukum Perdata Islam di Indonesia: Studi Kritis Perkembangan Hukum Islam dan Fiqih, UU No.1/1974 sampai KHI (Jakarta: Prenada Media, 2004), 38.

5 Amir Syarifuddin, Hukum Perkawinan Islam di Indonesia; Antara Fiqih Munakahat dan Undang-undang Perkawinan (Jakarta: Kencana, 2006), 35

6 T.0 Ihromi, Bunga Rampai Sosiologi Keluarga (Jakarta: Yayasan Obor, 2004), 137.

7 Subekti, Pokok-pokok Hukum Perdata (Jakarta: Inter Masa, 1996), 23. 
serta terjadi pertalian yang sah antara seorang pria dan seorang wanita dalam waktu yang lama.

\section{HUKUM PERKAWINAN}

Mazhab Malikiyyah, Syafiiyah dan Hanabilah menjelaskan bahwa hukum perkawinan (menikah) berbeda-beda tergantung keadaan seseorang. Pertama, menikah hukumnya wajib, yakni bagi mereka yang sudah siap dan mampu baik lahir maupun batin, sehingga apabila tidak menikah ia akan terjerumus kepada perbuatan zina. Kedua, menikah hukumnya sunnah, yakni bagi mereka yang syawatnya sudah menggebu tetapi ia masih dapat menjaga atau mengendalikan dirinya (nafsunya) dari perbuatan zina. Ketiga, menikah hukumnya makruh, yakni bagi mereka yang kondisinya belum siap, baik lahir maupun batin, tetapi tidak sampai menimbulkan madharat bagi mereka apabila menikah, oleh karenanya dalam kondisi seperti ini sebaiknya tidak menikah terlebih dahulu.

Keempat, menikah hukumnya haram, yakni bagi mereka yang belum siap menikah, baik lahir maupun batin, sehingga apabila dipaksakan menikah dapat menimbulkan madarat, atau menikah dengan maksud jahat, di mana dengan nikahnya ingin menyakiti istri dan keluarganya atau ingin balas dendam, dan lain sebagainya. Oleh karena itu berdasarkan penjelasan tersebut di atas, bahwa hukum menikah pada dasarnya bisa menjadi wajib, haram, sunnah, mubah dan makruh tergantung pada keadaan maslahat dan mafsadatnya. 


\section{RUKUN DAN SYARAT PERKAWINAN}

Terdapat beberapa pendapat mengenai rukun nikah sebagai berikut:

1. Menurut Jumhur ulama, bahwa rukun perkawinan ada empat, yakni ijab kabul (shighat), calon mempelai laki-laki, calon mempelai perempuan dan wali.

2. Menurut al-Zuhaili, bahwa dari sekian rukun nikah yang ada, hanya ada dua rukun perkawinan yang di sepakati ulama Fikih, yaitu ijab dan kabul, sedangkan sisanya hanyalah merupakan syarat perkawinan.

3. Menurut an-Nawawi, ${ }^{8}$ bahwa rukun perkawinan ada empat, yakni ijab dan kabul (shighat), calon mempelai laki-laki dan perempuan, saksi dan dua orang saksi.

4. Menurut al-Shirazi, ${ }^{9}$ bahwa rukun perkawinan tidak disebutkan secara tegas, beliau hanya menyebut kan sejumlah hal yang harus dipenuhi untuk sahnya perkawinan, yaitu harus ada wali, harus ada saksi, harus ada calon mempelai dan harus ada akad.

Terdapat beberapa pendapat mengenai rukun nikah sebagai berikut, di antaranya:

1. Menurut al-Zuhaili, bahwa perkawinan ada sepuluh hal, yakni halal menikahi antara para calon (tidak saling menghalangi untuk menikah), adanya ijab dan kabul (shighat), adanya saksi,

8 Abi Zakaria Yahya al-Nawawi al-Dimasyqi, Roudah at-Talibin (Beirut: Dar al-Kutub al-Ilmiyyah, 1412/1992), 382-400.

${ }_{9}$ Abi Ishaq Ibrahim al- Fairuz Abadi al-Syirazi, al-Muhazzab fi Fiqih alImam al-Syafi'i (Semarang: Toha Putra, t.t), 35-41. 
adanya kerelaan dan kemauan sendiri, adanya kejalasan pasangan yang akan melakukan perkawinan, calon suami istri tidak sedang melakukan haji/umroh, adanya suatu pemberian dari calon suami kepada calon istri (mahar), akad perkawinan tidak di sembunyikan (akad nikahnya jelas), tidak ada penyakit yang membahayakan antara kedunya atau salah satunya, dan adanya wali.

2. Menurut Fuqaha',10 bahwa syarat sahnya perkawinan antara lain terpenuhinya semua rukun perkawinan, terpenuhinya semua syarat nikah, dan tidak melanggar larangan perkawinan sebagaimana yang telah ditentukan syara'.

\section{ADMINISTRASI PERKAWINAN}

Administrasi dalam Kamus Bahasa Indonesia diistilahkan dengan pengertian Tata Usaha yaitu pekerjaan yang bertalian dengan tulis menulis, akan tetapi sebenarnya pengertian administrasi jauh lebih luas dari tata usaha. ${ }^{11}$ Sondang P. Siagian definisi administrasi adalah keseluruhan proses kerjasama dua orang atau lebih yang didasarkan atas rasinalitas tertentu untuk mencapai tujuan yang telah ditentukan sebelumnya. ${ }^{20}$ Sejalan dengan itu menurut Dwight Waldo yang dikutif Sarwoto mengemukakan hanya administrasi dalam pengertian modern adalah : Kegiatan manusia yang bekerjasama dengan tingkat rasionalitas yang tinggi. Ciri tingkat rasionalitas yang tinggi

10 Ibrahim Mayert dan Abd al-Halim Hasan, Pengantar Hukum Islam di Indonesia (Jakarta: Garuda, 1984), 333.

11 Departemen Pendidikan dan Kebudayaan, Kamus Besar Bahasa Indonesia (Jakarta: Balai Pustaka, 1990), 7.

20 Sondang P. Siagian, Filsafat Administrasi (Jakarta: Gunung Agung, 1985), 3. 
terletak pada kenyataan bahwa kerjasama manusia itu berbedabeda dalam efektifitas dalam tercapainya tujuan, baik tujuan formil (tujuan dari pada pimpinan-pimpinan kerja sama itu) maupun tujuan-tujuan dari pada seluruh anggota yang mengadakan kerjasama itu. ${ }^{21}$

Berdasarkan uraian di atas, pengertian administrasi mencakup usaha dan kegiatan yang meliputi penetapan tujuan serta penetapan cara-cara penyelenggaraan pembinaan organisasi, usaha dan kegiatan yang berkaitan untuk mencapai tujuan, kegiatan yang berkaitan dengan penyelenggaraan pemerintahan dan kegiatan kantor dan tata usaha.

Ada beberapa ketentuan dalam pencatatan pernikahan yang harus diketahui oleh para calon mempelai. Jika mempelai beragama selain Islam pencatatan dilakukan di kantor catatan sipil setempat, namun bagi mereka yang beragama Islam pencatatan dilakukan di kantor Urusan Agama (KUA) lebih dahulu baru baru dicatatkan kemudian di catatan sipil. Administrasi perkawinan meliputi sebagai berikut :

1. Fotocopy KTP dan Kartu Keluarga (KK) untuk calon Pengantin masing-masing 1 (satu) lembar.

2. Surat pernyataan belum pernah menikah (masih gadis/jejaka) di atas segel/materai senilai Rp.6000,- (enam ribu rupiah) diketahui RT, RW dan Lurah setempat.

3. Surat Pengantar RT - RW setempat. 6.

21 Sarwoto, Pengantar Administrasi Negara (Jakarta: Rineka Cipta,1987), 
4. Surat keterangan untuk nikah dari Kelurahan setempat yaitu Model N1, N2, N4, baik calon Suami maupun calon Istri.

5. Pas photo calon pengantin ukuran $2 \times 3$ masing-masing 4 (empat) lembar, bagi anggota BRI/TNI/POLRI harus berpakaian dinas.

6. Bagi yang berstatus duda/janda harus melampirkan Akta Cerai asli beserta salinan putusan berita acaranya dari Pengadilan Agama, kalau Duda/Janda mati harus ada surat kematian dan surat Model N6 dari Lurah setempat.

7. Harus ada izin/Dispensasi dari Pengadilan Agama bagi : Calon Pengantin Laki-laki yang umurnya kurang dari 19 (sembilan belas) tahun; Calon pengantin Perempuan yang umurnya kurang dari 19 (enam belas) tahun; Laki-laki yang mau berpoligami.

8. Ijin Orang Tua (Model N5) bagi calon pengantin yang umurnya kurang dari 21 (dua puluh satu) tahun baik calon pengantin laki-laki/perempuan.Bagi calon pengantin yang akan menikah bukan di wilayahnya (ke Kecamatan lain).

9. Harus ada surat Rekomendasi Nikah dari KUA setempat.

10. Bagi anggota TNI/POLRI dan Sipil TNI/POLRI harus ada surat Izin Kawin dari Pejabat Atasan/Komandan.

11. Kedua calon pengantin mendaftarkan diri ke KUA tempat akan dilangsungkannya akad nikah sekurang-kurangnya 10 (sepuluh) hari kerja dari waktu melangsungkan Pernikahan. Apabila kurang dari 10 (sepuluh) hari kerja, harus melampirkan surat Dispensasi Nikah dari Camat setempat. 


\section{PELAYANAN PRIMA}

Pelayanan prima merupakan bagian dari pelayanan publik, dimana pelayanan pubik merupakan salah satu bentuk produk dari birokrasi pemerintah yang bertindak sebagai organisasi publik. Kedudukan birokrasi adalah sebagai pelayanan, tugas pelayanan publik adalah memberikan pelayanan terhadap masyarakat tanpa kecuali dan tidak membeda-bedakan antara masyarakat satu dengan masyarakat yang lain.

Menurut Pasal 1 angka (1) Undang-Undang Nomor 25 Tahun 2009 tentang Pelayanan Publik menjelaskan bahwa pelayanan publik adalah kegiatan atau rangkaian kegiatan dalam rangka pemenuhan kebutuhan pelayanan sesuai dengan peraturan perundangan bagi setiap warga Negara dan penduduk atas barang, jasa atau pelayanan administratif yang disediakan oleh penyelenggara pelayanan publik.

Berdasarkan penjelasan undang-undang di atas, pelayanan publik dimaksudkan guna memberikan kepastian hukum dalam hubungan antara masyarakat dengan penyelenggara dalam pelayanan publik, artinya tujuan diadakannya undang-undang pelayanan publik tersebut ditujukan untuk terwujudnya batasan dan hubungan yang jelas tentang hak dan kewajiban serta tanggung jawab dan kewenangan seluruh npihak yang terkait dengan penyelenggaraan pelayanan publik. 
Konsep pelayanan prima ada 3 (tiga) macam, dimana konsep pelayanan prima tersebut meliputi sebagai berikut :

1. Konsep Sikap / Attitude, yakni sikap yang harus dimiliki diantaranya sikap yang ramah, penuh perhatian, dan memiliki rasa bangga terhadap perusahaan. Diharapkan para pegawai pada suatu perusahaan harus mencerminkan perusahaan itu sendiri. Karena para pegawai yang melayani konsumen akan mencerminkan citra perusahaan.

2. Konsep Perhatian / Attention, yaitu saat melakukan pelayanan kepada konsumen, maka perlu memperhatikan dan mencermati keinginan konsumennya.

3. Konsep tindakan / Action, misalnya seorang pegawai pada bagian pelayanan harus selalu memperhatikan dan mencermati apa yang menjadi keinginan konsumen. Jika pelanggan sudah menunjukan minat untuk membeli produk, maka segera layani pelanggan tersebut dan tawarkan bantuan yang mungkin dia butuhkan supaya pelanggan merasa puas terhadap pelayanan tersebut.

\section{PENCATATAN PERKAWINAN DI KUA DAN DI LUAR KUA}

Ketentuan pencatatan perkawinan merupakan suatu hal yang harus dilakukan bagi setiap orang yang akan menikah. Ketentuan pencatatan perkawinan dijelaskan dalam UU No 1 Tahun 1974 Tentang Perkawinan. Dalam Pasal 2 ayat (2) yang menjelaskan bahwa Tiap-tiap perkawinan dicatat menurut peraturan perundang- undangan yang berlaku. ketentuan ini bukan merupakan syarat sahnya nikah. Ketentuan ini merupakan 
bukti yang menunjukan kejelasan atas status pernikahan seseorang.

Islam juga memandang bahwa pencatatan perkawinan merupakan suatu keharusan, karena pencatatan nikah akan memberikan dampak bagi suami dan istri. Kekuatan dari pencatatan nikah juga untuk dapat membuktikan bahwa pernikahan yang dilakukan diakui oleh negara serta kejelasan anak dari hasil pernikahan tersebut. Akan tetapi, pencatatan nikah tidak termasuk kedalam rukun dan syarat nikah. Melihat kemudharatan yang lebih besar. Maka, pencatatan nikah dirasakan sangat penting demi menjamin hak hukum suami dan istri. "Menghilangkan kemudharatan itu lebih didahulukan daripada Mengambil sebuah kemaslahatan."

Dari beberapa aspek yang dapat dilihat berdasarkan tujuan dari pencatatan nikah adalah demi menjamin hak si istri dan suami serta menjami status anak dari hasil perkawinan tersebut. Maka, pencatatan nikah meskipun bukan dari bagian pernikahan tetapi harus dilakukan. Berdasarkan kaedah ; "Menghilangkan kemudharatan itu lebih didahulukan daripada mengambil sebuah kemaslahatan"dan "Kemudaratan/kerusakan harus dihilangkan".

Kedua kaedah tersebut cukup mewakili bahwa untuk menghilangkan kemudharatan yang timbul akibat pencatan nikah. Maka, pencatatan nikah dirasakan perlu untuk dilakukan oleh pihak mempelai.

Pada dasarnya tidak ada perbedaan pencatatan nikah di KUA dan di luar KUA. Hanya saja, dalam praktiknya perbedaan 
M. Ma'shum Ridho \& Abd. Qohar, Perspektif Hukum Islam Tentang Pernikahan .... 181 tersebut terlihat dari besar kecilnya pengeluaran uang yang akan di keluarkan bagi pihak yang ingin menikah. Pemerintah tidak membatasi terkait dengan apakah pencatatan nikah harus dilakukan di KUA atau di Luar KUA. Pencatatan nikah di luar KUA secara otomatis pihak mempelai harus mnghadirkan pihak KUA di tempat acara. Maka, secara tidak langsung pihak mempelai setidaknya menyiapkan sarana yang dibutuhkan oleh KUA. berbeda lagi jika pencatatan dilakukan di KUA yang menyiapkan fasilitas pernikahan seperti tempat adalah pihak KUA. Pemerintah tidak membatasi tempat pencatatan nikah, karena yang terpenting yaitu bahwa pihak yang berkewajiban mencatatat peristiwa nikah yaitu Penghulu sebagaimana yang dijelaskan dalam Pasal 2 PMA No 11 Tahun 2007 Tentang Pencatatan Nikah bahwa Pegawai Pencatat Nikah adalah pejabat yang melakukan pemeriksaan persyaratan, pengawasan dan pencatatan peristiwa nikah/rujuk, pendaftaran cerai talak, cerai gugat, dan melakukan bimbingan perkawinan.

\section{PRAKTIK PERNIKAHAN DI LUAR KUA BANDAR LAMPUNG}

Perihal pelaksanaan akad nikah telah diatur dalam KHI Pasal 28 yang menjelaskan bahwa Akad nikah dilaksanakan sendiri secara pribadi oleh wali nikah yang bersangkutan atau wali nikah mewakilkan kepada orang lain. Namun, dalam KHI tidak mengatur tentang tempat pelaksanaan akad nikah.kehadiran PMA No 11 Tahun 2007 Tentang Pencatatan Nikah bertujuan untuk melengkapi dari pasal 28 dalam KHI tersebut. Mengenai tempat pelaksanaan akad nikah diatur Pada pasal 21 Ayat (1) dan (2) PMA 
No 11 Tahun 2007 Tentang Pencatatan Nikah yang pada Ayar (1) menegaskan bahwa akad nikah dilaksanakan di KUA.

Kemudian pada ayat (2) dijelaskan juga bahwa akad nikah dapat dilaksanakan di luar KUA atas permintaan calon pengantin. Tujuan dari pasal ini yaitu untuk mengoptimalisasikan fungsi KUA sebagai balai nikah, sebagaimana yang dijelaskan oleh Kepala KUA Tanjungkarang Pusat Bapak H. Muhyiddin berikut ini;

Prinsip PMA No. 11 Tahun 2007 bahwa pernikahan harus dilaksanakan di Kantor Urusan Agama, adalah merupakan upaya optimalisasi fungsi Kantor Urusan Agama sebagai Balai Nikah dan mempermudah proses verifikasi sebelum dilakukan pencatatan pernikahan. Optimalisasi KUA sebagai Balai Nikah bagi umat Islam juga mempertegas bahwa Kantor Urusan Agama bukan sebagai satuan kerja memiliki unit kerja yang meliputi pembinaan berbagai agama, tetapi hanya sebagai unit kerja yang sekedar unit pelaksana teknis Direktorat Jendral Bimbingan Masyarakat Islam yang bertugas melaksanakan sebagian tugas Kantor Kementerian Agama Kota/Kab dibidang urusan agama Islam. ${ }^{12}$

Dalam penerapannya, yang paling banyak terjadi bahwa mayoritas masyarakat tidak memahami ketentuan pasal 21 ayat (1), yang menjadi tradisi dimasyarakat bahwa pernikahan dilakukan di luar KUA.Ini menunjukan bahwa ketentuan pasal 21 ayat (2) lebih efektif dalam pelaksanaannya. Hal ini disebabkan karena akad nikah tidak hanya berhubungan dengan agama dan

12 Wawancara dengan Bapak Kepala KUA Tanjung Karang Pusat, Selasa 10 Maret 2020. 
norma hukum saja melainkan berhubungan dengan budaya, klenik serta adat-adat yang telah menjadi suatu hal yang melekat pada masyarakat.

Sebagaimana yang disampaikan oleh Kepala KUA Kedaton Bapak H. Jalaluddin, ia mengatakan bahwa;

"Sebenarnya kalau Pasal itu memang menjelaskan bahwa pernikahan itu harus dilakukan di kantor urusan agama (KUA). Namun ada budaya yang tidak bisa dihilangkan bahwa masyarakat lebih memilih nikah diluar KUA. Jadi pernikahan itu berkenaan dengan agamis, budaya dan aturan. Artinya pernikahan berkenaan dengan peraturan ini harus dicatat, kalau kaitannya dengan agama. Maka, harus lengkap rukun dan syarat, kalau berkaitan dengan budaya biasanya adatnya itu dino iki, kalau klenik lebih ektrim lagi, kalau tidak hari itu pernikahan tidak bisa dilaksanakan.Makanya kalau melihat yang demikian memang pada Pasal 21 Ayat (1) menjelaskan bahwa akad nikah dilaksanakan di KUA.Ketentuan ini dibantu dengan Ayat 2 yang menejelaskan akad nikah bisa dilaksanakan di luar KUA atas permintaan mempelai dan atas persetujuan PPN. Ketentuan inilah yang jadi pedoman kita sehingga pernikahan dapat dilaksanakan di KUA dan di luar KUA.jadi yang berkenaan dengan agama, klenik, budaya dan peraturan ke empat hal ini bisa terpenuhi semua."13

Lebih lanjut bapak H. Jalaluddin menjelaskan jadi perlu memang diatur pelaksanaan nikah di luar kantor karena memang selama ini tidak ada. Mestinya kalau peraturan belum ada, pelaksanaan akad nikah harus di kantor semua. Selama ini yang menjadi polemik yaitu tentang biaya pencatatan nikah dan biaya pelaksanaan akad nikahnya. Jadi menurut pandangan saya, kita masih menganut pada hukum yang ada. Bagaimana persoalannya 
ketika ternyata masyarakat maunya pencatatan di luar kantor atau diluar jam kerja sedangkan hal itu gak ada peraturannya, akhirnya harus ada kebijakan. Jika selama ini KUA masih mengabulkan permohonan di luar kantor, itu karena mengakomodir aspirasi publik. Memang disyariatkan pernikahan itu agar diramaikan, kemudian dilaksanakan di mesjid-mesjid atau mengundang sebagian banyak orang. Jadi menurut pandangan kami peraturan pemerintah yang mengatur tentang biaya pencatatan nikah ada yang kurang, jadi peraturan tersebut juga harus mengatur tentang bagaimana pelaksanaan akan nikah di luar kantor KUA.

Kebudayaan memang tidak bisa dilepaskan dari kehidupan bermasyarakat, budaya dalam akad nikah merupakan suatu rangkaian yang dianggap sakral, disetiap daerah tentu memiliki perbeda dalam pelaksanaannya. Berbeda lagi jika kita berbicara tentang adat jawa (adat kejawen). Dalam perjalanannya meskipun masyarakat lebih memilih melaksanakan akad nikah di luar KUA. Namun, tatap saja kepala KUA menyarankan agar pelaksanaan akad nikah dilakukan di KUA, karena hal ini sudah menjadi ketentuan dari pemerintah, berkaitan dengan masyarakat memilih pelaksanaannya di luar KUA. Maka, dapat dikabulkan oleh PPN karena mengingat PMA Pasal 21 Ayat (2) membolehkannya. Tapi ketentuan ini banyak mendatangkan problematika dalam implementasinya.

Kepala KUA Panjang Bapak H. Purna Irawan menjelasan bahwa Kementerian Agama merupakan representasi wajah umat beragama di Indonesia, dan Kantor Urusan Agama lah yang 
M. Ma'shum Ridho \& Abd. Qohar, Perspektif Hukum Islam Tentang Pernikahan .... 185 menjadi garda terdepannya. Oleh karena itu tolak ukur keberhasilan pelaksanaan tugas dan fungsi Kementerian Agama ditentukan juga oleh keberhasilan pelaksanaan tugas dan fungsi Kantor Urusan Agama. Akan tetapi semua itu memerlukan dukungan dan sinergi dengan berbagai pihak, baik lintas kementerian/lembaga, dengan pemerintah daerah serta para tokoh agama dan masyarakat. ${ }^{14}$

Pada era reformasi saat ini transparansi, ketika akuntabilitas dan kejujuran publik menjadi agenda utama, maka reformasi dan perubahan struktur birokrasi yang bermakna reorientasi, reformasi dan refungsionalisasi, mutlak diperlukan untuk mencapai efektivitas danefisiensi organisasi. Oleh karena itulah, tugas dan fungsi pejabat dalam birokrasi diharapkan dapat optimal dalam pelayanan dan pengayoman hajat hidup masyarakat. Perubahan struktur, peran dan fungsi birokrasi tersebut sekaligus mengandung makna bahwa setiap birokrat dituntut memiliki semangat kemasyarakatan dan pengabdian. Salah satu bentuk nyata reformasi di bidang pelaksanaan tugas dan fungsi Kantor Urusan Agama adalah dengan diterbitkannya Keputusan Menteri Agama Republik Indonesia Nomor 47 Tahun 2004 Tentang Pencatatan Nikah, yang mencabut tugas dan wewenang PPN serta dialihkan kepada Institusi Kepenghuluan, yang dalam konteks ini adalah Penghulu dan Pembantu Penghulu. Perubahan piranti tersebut, meskipun bukan peristiwa yang luar biasa, tetapi setidaknya akan membawa implikasi dan perubahan suasana baru secara struktural, sosial dan psikologis. 
Hal ini menurut Bapak H.Muhyiddin selaku Kepala KUA Tanjungkarang Pusat yaitu tentunya merupakan tantangan sekaligus sebagai kepercayaan yang perlu mendapat apresiasi secara seksama, sehingga jabatan penghulu bukan saja sebagai corong yang piawai melaksanakan tupoksinya, tetapi juga handal dalam menghadapi dan menyelesaikan persoalan umat. Dalam melaksanakan tugasnya, penghulu disamping harus berpedoman pada Juklak dan Juknis Kepenghuluan, ternyata harus memperhatikan juga unsur lain yaitu agama, budaya, tradisi, gengsi dan klenik daerah tempat tugasnya. Jadi, tugas kepenghuluan bukan urusan administrasi semata. Tak terkecuali di kecamatan Tanjungkarang Pusat Berlakunya Peraturan Pemerintah No. 19 Tahun 2015 bagi pihak Kantor Urusan Agama kecamatan Tanjungkarang Pusat merupakan angin segar sekaligus tantangan baru. Menjadi angin segar karena merupakan perisai atas ancaman gratifikasi, tetapi juga menjadi tantangan karena merupakan pekerjaan rumah untuk bagaimana meningkatkan mutu pelayanan nikah sekaligus mewujudkan layanan nikah yang berintegritas. ${ }^{15}$

Dalam rangka mewujudkan layanan nikah yang berintegritas, jika dihubungkan dengan pelaksanaan Peraturan Pemerintah Nomor 19 Tahun 2015 pihak KUA mensinyalir adanya beberapa peluang sekaligus hambatan. Peluang dan hambatan tersebut antara lain:

15 Wawancara dengan Bapak Kepala KUA Tanjung Karang Pusat, Selasa 10 Maret 2020 
1. Tradisi masyarakat yang menikahkan anak atau keluarganya di rumah. Tradisi ini dapat menjadi peluang menambah persentase sosialisasi peraturan dan program KUA, sarana mendekatkan diri dengan masyarakat dan sarana menampung aspirasi dan sharing atas pelayanan KUA. Tradisi ini dapat juga menjadi hambatan ketika tradisi menjadi penentu pelaksanaan nikah, dalam arti waktu pelaksanaan menjadi otoritas wali nikah, kemungkinan membatalkan acara secara sepihak dan dalam acara pelaksanaan digabung dengana cara adat sorong serah/aji krama mengakibatkan acara menjadi panjang dan bertele-tele.

2. Transport penghulu yang melaksanakan tugas menikahkan di luar kantor sebagaimana diatur dalam PP.19 Tahun 2015. Hal ini dapat menjadi peluang meningkatkan kinerja penghulu sekaligus perisai terhormat untuk menangkis gratifikasi, tetapi dapat menjadi halangan ketika pendistribusiannya tak lancar dan tak sesuai dengan harapan.

3. Sarana Balai Nikah, dapat menjadi peluang untuk memberikan pelayanan nikah di kantor sekaligus meminimalisir isu gratifikasi. Di sisi lain dapat menjadi hambatan ketika masyarakat menilai sarana tersebut belum dapat meningkatkan alasan mereka memilih nikah di kantor KUA.

Angin segar yang dirasakan oleh pihak KUA Tanjung Karang Pusat, Kedaton dan Panjang dengan berlakunya Peraturan Pemerintah No. 19 Tahun 2015, ditindaklanjuti dengan beberapa langkah konkrit Sosialisasi tentang Peraturan Pemerintah No. 19 
Tahun 2015 yang mengatur tentang perubahan tarif atas jenis Penerimaan Negara Bukan Pajak (Biaya Nikah/rujuk) baik melalui Surat Permakluman, Memberikan pemahaman dan pembuktian kepada masyarakat bahwa KUA anti gratifikasi

Dari kajian tersebut, pihak KUA akhirnya melakukan pilihan untuk mengupayakan masyarakat memilih nikah dalam kantor. Terlebih dengan tingkat pemahaman masyarakat yang berbeda terkait isu gratifikasi. Meski telah dilakukan sosialisasi bahwa biaya Rp. 600.000 adalah biaya resmi nikah yang mempunyai kekuatan hukum tetap, isu gratifikasi masih saja digumamkan oleh masyarakat.

Berdasarkan hasil kajian seperti di atas, maka sosialisasi tentang PP.19/2015 ditambah dengan promosi nikah dalam kantor. Dengan semangat memberikan pelayanan nikah yang berintegritas, pihak KUA Panjang, Kedaton dan Tanjung Karang tak jemu-jemu melakukan promosi nikah dalam kantor dengan menguraikan dua pertimbangan kepada masyarakat yaitu pertimbangan akumulasi biaya. Dan pelayanan kepada calon pengantin yang menikah dalam kantor sama baiknya dengan calon pengantin yang menikah di luar kantor

\section{FAKTOR YANG MENYEBABKAN TERJADINYA PERNIKAHAN DI LUAR KUA BANDAR LAMPUNG}

Menurut pendapat Bapak Purna Irawan selaku Kepala KUA Panjang bahwa terkadang berbeda apa yang difikirkan oleh masyarakat kota dan masyarakat awam. Bagi masyarakat awam 
(tradisional) pada setiap akad nikah harus melalui perhitungan jawa. Jika perhitungan tersebut berkaitan dengan hari, jam dan kecocokan calon mempelai telah ditentukan. Maka, tidak dapat dirubah dengan hal yang lain karena itu sudah menjadi sakral. Oleh karenanya, terkadang banyak yang menikah pada hari libur dan diluar kantor dan pihak KUA harus bisa mengakomodir nilai yang telah tertanam pada masyarakat, karena nikah merupakan suatu ketentuan yang secara Syar"i harus terpenuhi dan secara adat harus terpenuhi.

Faktor budaya sangat berpengaruh dalam penerapan suatu peraturan. Menurut Lawrence M. Friedman bahwa kekuatankekuatan sosial terus-menerus menggerakkan hukum merusak dan memperbaharui. Budaya memiliki kekuatan pengubah dalam penegakan hukum, kekuatan budaya seperti ini disebut oleh Friedman sebagai kultur hukum. Menurutnya, kultur hukum adalah elemen sikap dan nilai sosial atau diistilahkan sebagai "kekuatan-kekuatan sosial". Kultur hukum adalah suatu bentuk opini-opini, kepercayaan, keyakinan, kebiasaan, cara berfikir, cara bertindak baik dari lembaga hukum maupun dari masyarakat.

Dapat dilihat bahwa menikah di luar KUA dengan membayar uang sebesar 600.000 seakan-akan tidak manjadi suatu pilihan bahkan telah menjadi suatu prioritas. Tidak bisa dipungkiri bahwa pernikahan merupakan kebutuhan begitu juga dengan tempat pelaksanaan akad nikah yang merupakan suatu kebutuhan yang tidak bisa diatur oleh pemerintah. Jika itu termasuk kedalam kebutuhan masyarakat. Maka, pemerintah tidak dapat membatasi pernikahan seseorang dengan membatasi waktu dan tempat. Jika 
memang pernikahan harus dilakukan di KUA. hal ini berarti KUA tetap bekerjapada hari libur, karena mengingat terkadang masyarakat banyak yang menikah pada hari libur.

Selain mengandung nilai agama dan budaya, akad nikah memiliki nilai kesakralan yang menjadikan pernikahan tersebut sangat berharga sehingga dibutuhkan tempat yang dapat menggambarkan kondisi seperti itu. Oleh karena itu, masyarakat lebih memilih akad nikah di rumah, di masjid atau di gedung. Tujuannya adalah untuk mendapatkan kesan yang lebih dari acara tersebut. Selain akad nikah di luar KUA merupakan sebagai bentuk tradisi. Pada aspek yang lain bahwa pernikahan yang dilakukan di KUA memberi image yang berbeda bagi sebagian masyrakat. Sebagian masyarakat merasa bahwa pernikahan di KUA membawa image negatif bagi pihak mempelai. Namun, tidak semua masyarakat berfikiran seperti itu. Anggapan yang muncul yaitu bahwa jika menikah di KUA tanpa disaksikan orang banyak agat tidak dikatehui aib nya.

Berdasarkan data yang didapati dari berbagai narasumber dengan pelapisan sosial yang berbeda. Maka, Dalam hal ini peneliti memasukan kedalam kategori kelompok memagis-religius yaitu : Ibu Revi Anita, Ibu Siti Atiyah, Ibu Anita Sari, Bapak Selamat Riady, Bapak Agus Maulana, Ibu Ayu Wulandari, Bapak Muhammad Subhan, Bapak Gusnidar Pratama, Ibu Anisa Rahmawati, Ibu Desi Kurniawati, Ibu Ayu Narwati, Bapak Rizwan Pralingga, Bapak Abdul Rosyid, Bapak Ilham Rizky, dan Bapak Puadi. 
Masyarakat tradisional, mengutip pendapat Weber (18641920) yang dikatakan masyarakat tradisional yaitu masyarakat yang patuh dalam menjalankan pesan keagamaannya. Kelompok masyarakat ini dalam menjalankan akad nikah yang menjadi acuan utama yaitu hukum islam. Bagi masyarakat tradisional mereka lebih memilik aqad nikah di mesjid karena terdapat nilai-nilai ibadah dan dapat didoakan oleh pemuka agama.berbeda dengan masyarakat magis-religuis nilai adat tetap dipertahankan disamping nilai-nilai agama tidak diabaikan. Pada masyarakat seperti ini masih melihat nilai-nilai tradisi dalam pernikahan, seperti penetapan hari, jam, tempat dan kecocokan mempelai berdasarkan hitungan weton dan primbon. Ada beberapa faktor yang menyebabkan masyarakat lebih memilih akad nikah di luar KUA, antara lain; Faktor adat / tradisi; Lebih khidmat, sakral, nyaman dan berkesan; Dapat disaksikan orangbanyak; Menghindari gosip dan image negative; Lebih mudah, simple dan praktis.

Alasan tersebut jika diklasifikasikan ada yang berdasarkan faktor tradisi ada juga di landasi faktor kemudahan dan kenyamanan. Alasan tersebut dihasilkan dari pernyataan berbagai narasuber dengan latar belakang sosial yang berbeda.

Perbenturan tersebut berkaitan dengan hukum, budaya dan juga agama. Disatu sisi peraturan mengatur agar akad nikah di KUA, disatu sisi pernikahan merupakan tuntunan agama dan juga mengandung unsur budaya yang tidak dapat dipisahkan. Sehingga konflik yang terjadi yaitu bahwa masyarakat lebih memilih budaya 
yang telah mereka yakini terlebih dahulu sejak ratusan tahun yang lalu.

Tradisi menikahkan anak atau keluarga di rumah masih menjadi pilihan utama pada KUA Kecamatan Tanjung Karang Pusat, Kedaton dan Panjang pada Tahun 2017-2019, sebagaimana berikut :

1. Besaran biaya nikah luar kantor memang tidak menjadi kendala utama masyarakat untuk melangsungkan pernikahan di rumah. Bagi mereka, nikah di luar kantor tetap menjadi pilihan utama didukung oleh alasan tradisi, disamping juga beberapa alasan.

2. Untuk pelaksanaan pernikahan di KUA ternyata lebih memboroskan, ruangan balai nikah yang tidak memadai, dan perasaan kurang puas dan kurang sreg kepada keluarga pengantin wanita, sebenarnya akan terjawab dengan melakukan permakluman kepada keluarga calon pengantin wanita tentang jauh dekatnya jarak KUA dengan rumah pengantin pria. Solusi lainnya adalah dengan membagi rombongan keluarga pengantin wanita itu, sebagian rombongan yang terdiri wali nikah dan beberapa saksi menuju ke KUA dan sebagian lagi langsung menuju rumah pengantin pria.

Meskipun perkawinan dilakukan di KUA lebih murah biayanya daripada dilaksanakan di luar KUA, tetapi banyak masyarakat lebih memilih untuk menikah di luar KUA karena terdapat maslahatnya, contohnya terhindar dari berbagai fitnah 
dan image negarive. Melalui pendekatan sosiologis, terjalinnya hubungan komunikasi antar masyarakat, karena jika pernikahan di laksanakan di KUA, masyarakat tetangga tidak bisa menikmati momen sakral dan kegembiraan karena di laksanakan pada hari dan jam kerja, dan hubungan sosial antar masyarakat semakin akrab jika suatu pernikahan di laksanakan di rumah atau di luar KUA, karena di masyarakat apabila suatu pernikahan akan di langsungkan maka tetangga dan masyarakat ikut membantu, mulai dari persiapan konsumsi, masak memasak hingga persiapan dekorasi tenda dan lain sebagainya sehingga terjalinlah hubungan yang sangat harmonis di dalam masyarakat.

\section{KESIMPULAN}

Faktor yang menyebabkan masyarakat lebih memilih akad nikah di luar KUA, antara lain; Faktor adat / tradisi, Lebih khidmat, sakral, nyaman dan berkesan, Dapat disaksikan orangbanyak, Menghindari gosip dan image negative, serta lebih mudah, simple dan praktis. Alasan tersebut jika diklasifikasikan ada yang berdasarkan faktor tradisi ada juga didilandasi faktor kemudahan dan kenyamanan. Alasan tersebut dihasilkan dari pernyataan berbagai narasumber dengan latar belakang sosial yang berbeda. Masing-masing memiliki alasan tersendiri. Namun masih banyaknya asumsi masyarakat yang menilai pelaksanaan menikah dikantor KUA mengeluarkan biaya yang tidak sedikit. Peningkatan pelaksanaan pernikahan diluar KUA karena kurangnya sosialisasi yang dilakukan oleh pihak KUA kecamatan Tanjung Karang, 
Kedaton dan Panjang efektifnya pelaksanaan pernikahan dikantor KUA.

\section{DAFTAR PUSTAKA}

al-Dimasyqi, Abi Zakaria Yahya al-Nawawi. Roudah at-Talibi. Beirut: Dar al-Kutub al-Ilmiyyah, 1412/1992.

al-Syirazi, Abi Ishaq Ibrahim al- Fairuz Abadi, al-Muhazzab fi Fiqih al-Imam al-Syafi'i, Semarang : Toha Putra, t.t.

Departemen Pendidikan dan Kebudayaan. Kamus Besar Bahasa Indonesia. Jakarta: Balai Pustaka, 1990.

Ihromi, T.O. Bunga Rampai Sosiologi Keluarga. Jakarta: Yayasan Obor, 2004.

Lubis, Nur A Fadhil. Hukum Islam Dalam Kerangka Teori Fikih dan Tata Hukum Indonesia. Medan: Widiyasarana, 1995.

Mayert, Ibrahim dan Abd al-Halim Hasan. Pengantar Hukum Islam di Indonesia. Jakarta: Garuda, 1984.

Nuruddin, Amir \& Tarigan, Azhar Akmal. Hukum Perdata Islam di Indonesia : Studi Kritis Perkembangan Hukum Islam dan Fiqih, UU No.1/1974 sampai KHI. Jakarta: Prenada Media, 2004.

Sarwoto. Pengantar Administrasi Negara. Jakarta: Rineka Cipta,1987.

Siagian, Sondang P. Filsafat Administrasi. Jakarta: Gunung Agung, 1985.

Subekti. Pokok-pokok Hukum Perdata. Jakarta: Inter Masa, 1996.

Syarifuddin, Amir. Hukum Perkawinan Islam di Indonesia; Antara

Fiqih Munakahat dan Undang-undang Perkawinan. Jakarta: Kencana, 2006.

Yunus, Mahmud. Kamus Arab Indonesia. Jakarta: Yayasan Penyelenggara Penterjemah/ Pentafsiran Al-Qur'an, 1973. Undang-undang Nomor 1 Tahun 1974 tentang Perkawinan.

Wawancara dengan Bapak Kepala KUA Kedaton, Senin 16 Maret 2020.

Wawancara dengan Bapak Kepala KUA Panjang, Selasa 14 April 2020.

Wawancara dengan Bapak Kepala KUA Tanjung Karang Pusat, Selasa 10 Maret 2020. 